\title{
A Monoclonal Antibody Recognizes a von Willebrand Factor Domain within the Amino-terminal Portion of the Subunit that Modulates the Function of the Glycoprotein IB- and IIB/IIIA-binding Domains
}

\author{
Istvan Tornai, Jef Arnout, Hans Deckmyn, Kathelijne Peerlinck, and Jos Vermylen \\ Center for Thrombosis and Vascular Research, University of Leuven, B-3000 Leuven, Belgium
}

\begin{abstract}
We developed a monoclonal antibody, 1C1E7, against vWf that increases ristocetin-induced platelet aggregation in a dose-dependent manner and lowers the threshold concentration of ristocetin needed to obtain a full aggregatory response. The platelet aggregatory effect of asialo vWf (ASvWf) also is enhanced by $1 \mathrm{C1E} 7$, in the presence or absence of glycoprotein (GP) IIb/IIIa receptor antagonism. In the presence of ristocetin, both intact $1 \mathrm{C1E} 7$ and its Fab fragments enhance specific binding of ${ }^{125} \mathrm{I}-\mathrm{vWf}$ to platelets. With $1 \mathrm{C1E7}$, the intermediate and higher molecular weight multimers of vWf are preferentially bound to both GP Ib and GP IIb/IIIa. Thrombin-induced ${ }^{125}$ IvWf binding to GP IIb/IIIa also is increased by 1C1E7. Maximal binding of 1C1E7 to $\mathrm{vWf}$ corresponds to $0.97 \mathrm{~mol} / \mathrm{mol}$ vWf monomer with a $K_{d}$ of $4.7 \times 10^{-10} \mathrm{M} .1 \mathrm{C} 1 \mathrm{E} 7$ reacts with a 34/36-kD tryptic fragment (III-T4) and a 34-kD plasmic fragment (P34), which localizes the epitope between amino acid residues 1 and 272; this was confirmed by $\mathrm{NH}_{2}$-terminal amino acid sequencing. Finally, platelet aggregation by ASvWf was associated with a sharp rise in intracellular $\mathrm{Ca}^{2+}$ only in the presence of 1C1E7. An antibody-mediated conformational change of $\mathrm{vWf}$ may result in an improved presentation of the GP Ib- and GP IIb/IIIa-binding domains of mainly the larger multimers; the increased density of $\mathrm{vWf}$ on the platelet surface leads to platelet activation. The antibody may thus recognize a domain of relevance for $\mathrm{vWf}$ physiology. (J. Clin. Invest. 1993. 91:273-282.) Key words: von Willebrand factor • platelets • ristocetin • monoclonal antibody
\end{abstract}

\section{Introduction}

Adhesion of blood platelets to an injured vessel wall is the first and crucial step of primary hemostasis. $\mathrm{vWf}$ has a central role in platelet adhesion and additionally is a carrier protein for coagulation factor VIII (1). It is a large multimeric protein built from identical subunits (2). The assembly of subunits gives rise to a series of multimers with molecular masses varying between 500 and $20,000 \mathrm{kD}$. The largest multimers are generally considered to be the hemostatically most active (3); however, all the essential information needed for the function

Address correspondence to Professor J. Vermylen, M. D., Center for Thrombosis and Vascular Research, University of Leuven, Herestraat 49, B-3000 Leuven, Belgium.

Received for publication 19 February 1992 and in revised form 20 July 1992.

J. Clin. Invest.

(C) The American Society for Clinical Investigation, Inc.

$0021-9738 / 93 / 01 / 0273 / 10 \quad \$ 2.00$

Volume 91, January 1993, 273-282 of vWf resides in the basal subunit (4). During the past decade, several functional domains have been identified on the subunit using proteolytic enzymes (5), mAbs (6), and/or overlapping synthetic peptides (7). vWf mediates platelet adhesion through binding to an as yet unidentified component of the subendothelium and to different types of collagen $(8,9)$. This interaction probably causes a conformational change in the structure of $\mathrm{vWf}(10)$, upon which $\mathrm{vWf}$ can bind to the platelet glycoprotein (GP) ${ }^{1}$ Ib receptor; this is followed by platelet activation and exposure of the GP IIb/IIIa receptor by so far ill-defined mechanisms. After the exposure of GP IIb/IIIa, this receptor becomes available for $\mathrm{vWf}$ as well as for other adhesive proteins. However, in in vitro conditions, the vWf-GP Ib interaction requires ristocetin or botrocetin (11); vWf binds exclusively to GP IIb/IIIa after platelet activation by thrombin or $\operatorname{ADP}(12)$.

Several $\mathrm{mAbs}$, raised against vWf, block specific functions by binding to a certain region of the molecule $(13,14)$. In this study we report on a mAb that instead stimulates the function of vWf, by increasing its interaction with both platelet GP Ib and IIb/IIIa, although the antibody binds to a region that is located at a distance from both binding domains.

\section{Methods}

\section{Preparation of blood samples}

Blood was collected on trisodium citrate, $\mathrm{pH} 7.5(0.11 \mathrm{M}, 0.1 \mathrm{vol})$ and immediately centrifuged at $180 \mathrm{~g}$ for $10 \mathrm{~min}$ to obtain platelet-rich plasma (PRP).

Gel-filtered platelets were prepared using a modification of the technique described by Tangen and Berman (15). Blood was taken on $1 / 6$ vol of acid citrate dextrose anticoagulant and PRP was passed through a Sepharose 2B column (Pharmacia LKB Biotechnology Inc., Uppsala, Sweden ) equilibrated with Hepes buffer (16), $\mathrm{pH} 7.35$, with the following composition $(\mathrm{mM}): 3.5 \mathrm{Hepes}, 137 \mathrm{NaCl}, 2.7 \mathrm{KCl}, 1.0 \mathrm{MgCl}_{2}, 3.0$ $\mathrm{NaH}_{2} \mathrm{PO}_{4}, 5.5$ glucose, $0.1 \%$ BSA (Organon Teknika, Bextel, The Netherlands). One additional washing step was used to further reduce the amount of contaminating plasma vWf, so that no agglutination of washed platelets occurred in response to the addition of $1.5 \mathrm{mg} / \mathrm{ml}$ ristocetin (Lundbeck, Copenhagen, Denmark), unless vWf was added to the suspension.

\section{Purification of $v W f$}

$\mathrm{vWf}$ was purified to homogeneity from lyophilized cryoprecipitate using a gel filtration method, as previously described (17). These preparations were used for binding experiments and preparation of asialo $\mathrm{vWf}$ (ASvWf).

1. Abbreviations used in this paper: ASvWf, asialo vWf; DFP, diisopropyl fluorophosphate; GP, glycoprotein; RiCoF, ristocetin cofactor; RIPA, ristocetin-induced platelet aggregation; TBS, Tris-buffered saline. 
vWf was also isolated by immunoaffinity purification (18). Cryoprecipitate was dissolved in $0.02 \mathrm{M}$ imidazole, $0.1 \mathrm{M}$ L-lysine, $0.15 \mathrm{M}$ $\mathrm{NaCl}, 0.02 \% \mathrm{Na}$ azide, $\mathrm{pH} 6.8$, and was applied to a $\mathrm{CNBr}$-activated Sepharose 4B (Pharmacia LKB Biotechnology Inc.) column to which an anti-vWf mAb, 82D6A3 (see below), was coupled. The vWf bound to the antibody was eluted with $3 \mathrm{M}$ NaSCN dissolved in the same buffer. The eluted vWf was dialyzed extensively against Tris-buffered saline (TBS) with the following composition (mM): 20 Tris, $150 \mathrm{NaCl}$, $\mathrm{pH}$ 7.4. These preparations were only used for proteolytic digestions.

The purity of these preparations was checked in SDS-PAGE (19) followed by Coomassie blue staining or Western blotting (20). Protein concentrations of the preparations were determined by the method of Bradford (21), using BSA as a standard. The specific activity of the preparations varied between 80 and $130 \mathrm{U} / \mathrm{mg}$ of vWf. One unit of $\mathrm{vWf}$ is defined as the amount of activity or antigen level found in $1 \mathrm{ml}$ of pooled normal plasma.

\section{Preparation of $A S v W f$}

Purified vWf was incubated with proteinase-free neuraminidase from Vibrio cholerae (Calbiochem Corp., La Jolla, CA) at a concentration of 0.15 to $0.20 \mathrm{U} / \mathrm{mg} \mathrm{vWf}$ in the presence of $8 \mathrm{mM} \mathrm{CaCl}_{2}, \mathrm{pH} 6.8$, at $37^{\circ} \mathrm{C}$ for $3 \mathrm{~h}$, as described (22). Then it was passed through a Sepharose CL-4B column to remove the enzyme. ASvWf was analyzed for sialic acid content, ristocetin cofactor ( $\mathrm{RiCoF}$ ) activity, and electrophoretic mobility, unreduced in SDS-agarose gel electrophoresis and reduced in SDS-PAGE. Sialic acid content was measured according to Warren (23) and $>90 \%$ of that of the native vWf was removed. The multimeric structure and $\mathrm{RiCoF}$ activity were identical to those of native vWf.

\section{Preparation of $m A b s$}

mAbs against $\mathrm{vWf}$ were produced by conventional hybridoma technology as previously described (17). The IgG fractions were purified from ascites by affinity chromatography on protein A-Sepharose (Pharmacia LKB Biotechnology Inc.) (24). Finally, we obtained six mAbs (1C1E7, 2B1D6, 4H1D7, 82D1E1, 82D6A3, and 76E7H7) that reacted specifically with purified $\mathrm{vWf}$, using electroimmunoblotting after SDS-PAGE under reducing and nonreducing conditions; no cross-reactivity with fibrinogen or fibronectin could be observed.

A mAb against platelet GP IIb/IIIa, 16N7C2, also has been developed and was found to fully inhibit all fibrinogen-dependent platelet aggregations and binding of ${ }^{125} \mathrm{I}-\mathrm{vWf}$ to washed thrombin-activated platelets at a concentration of $20 \mu \mathrm{g} / \mathrm{ml} \mathrm{(25).}$

\section{Preparation of the Fab fragment of $m A b$ IC1E7}

Fab fragments were prepared, using papain (Sigma Chemical Co., St. Louis, MO) in the presence of $0.01 \mathrm{M}$ cysteine as described (26). The $F_{c}$ fragment was removed by chromatography on protein A-Sepharose. Fab preparations of $1 \mathrm{C} 1 \mathrm{E} 7$ were virtually free of intact $\mathrm{IgG}$ and $\mathrm{F}\left(\mathrm{ab}^{\prime}\right)_{2}$ fragments as was shown on SDS-PAGE.

\section{Platelet aggregation assays}

The aggregating response of platelets in PRP or after gel filtration was evaluated with a turbidimetric aggregometer (Elvi, Milan, Italy). The agonists and final concentrations used were ristocetin, $0.5-1.2 \mathrm{mg} / \mathrm{ml}$; ADP, 1.0-2.0 $\mu \mathrm{M}$ (Sigma Chemical Co.); collagen, 0.5-2.0 $\mu \mathrm{g} / \mathrm{ml}$ (Hormon-Chemie, Munich, Germany); arachidonic acid, 0.5-1.0 $\mathrm{mM}$ (Sigma Chemical Co.); and epinephrine, 30-40 $\mu \mathrm{M}$ (Sigma Chemical Co.). When the effect of anti-vWf mAbs on platelet aggregation was evaluated, the $\mathrm{mAb}$ was preincubated with PRP for $30 \mathrm{~min}$ at room temperature before the addition of the inducer. The $\mathrm{vWf} \mathrm{RiCoF}$ activity was measured according to MacFarlane et al. (27) using fresh washed platelets.

\section{Binding experiments}

In all binding experiments, which were performed according to Ruggeri et al. (28), platelets were at a final concentration of $10^{8} / \mathrm{ml}$ in
Hepes buffer. vWf or ASvWf were labeled with $\mathrm{Na}^{125} \mathrm{I}$ (Amersham International, Amersham, UK) to a specific activity of $0.7-3.0 \mathrm{mCi} /$ $\mathrm{mg}$ as previously described (29). Incubation with varying concentrations of ${ }^{125} \mathrm{I}-\mathrm{vWf}$ and the appropriate stimulus was performed at room temperature under nonstirring conditions for $30 \mathrm{~min}$. At the end of the incubation period, $100 \mu \mathrm{l}$ of the platelet suspension was layered onto $300 \mu \mathrm{l}$ of $20 \%$ sucrose in the Hepes buffer, using Eppendorf tubes. The samples were centrifuged for $5 \mathrm{~min}$ at $13,000 \mathrm{~g}$ in a microcentrifuge (Sigma Chemical GmbH, Munich, Germany). The supernatants were carefully removed and the tips of the tubes, containing the platelet pellet, were amputated and the platelet-associated radioactivity was measured in a gamma counter (Packard Instrument Co., Inc., Canberra Industries, Meriden, CT). When the effect of $1 \mathrm{C} 1 \mathrm{E} 7$ on ${ }^{125} \mathrm{I}-\mathrm{vWf}$ binding to platelets was evaluated, $\mathrm{mAb}$ was preincubated with ${ }^{125} \mathrm{I}$ $\mathrm{vWf}$ for $30 \mathrm{~min}$ at room temperature before addition to the platelet suspension. In the control experiments, either buffer or a comparable amount of an irrelevant mouse $\mathrm{mAb}$ was used in the preincubation step. This control $\mathrm{mAb}, 7 \mathrm{C7}$, raised against urokinase, had no influence on either vWf or platelet function. When the effect of mAbs inhibiting platelet GP Ib (AP 1, [30] a generous gift of T. J. Kunicki, The Blood Center of SE Wisconsin, Milwaukee) or GP IIb/IIIa (16N7C2) was investigated, the monoclonal IgG was added to the platelet suspension at the indicated final concentration, which gave $>90 \%$ saturation of that particular GP, 10 min before addition of radioligand and stimulus. Nonspecific binding was determined either in the presence of a 50-fold excess of unlabeled vWf or in the absence of the stimulus. Both have been reported to result in identical values $(28,31)$, a finding that we also could confirm. Scatchard and Hill plots were used to analyze the binding curves. Because of the large molecular mass range of $\mathrm{vWf}$, maximal binding was expressed as $\mu \mathrm{g} / 10^{8}$ platelets. Binding of ${ }^{125} \mathrm{I}-$ ASvWf was performed in PRP in a similar manner (32).

\section{Multimeric analysis of ${ }^{125} \mathrm{I}-\mathrm{v} W \mathrm{~W}$ bound to platelets}

Multimeric analysis of the ${ }^{125} \mathrm{I}-\mathrm{vWf}$ bound to either ristocetin- or thrombin-stimulated platelets (as above) was performed by lysing the platelet pellet with $50 \mu \mathrm{l}$ of a $10 \mathrm{mM}$ Tris buffer, $\mathrm{pH} \mathrm{8.0,} \mathrm{containing} 1$ mM EDTA, $8 \mathrm{M}$ urea, and 5\% SDS (28). The samples were incubated at $60^{\circ} \mathrm{C}$ for $30 \mathrm{~min}$. More than $70 \%$ of the platelet-associated radioactivity could be recovered in the supernatant of the platelet lysates. The extracted ${ }^{125} \mathrm{I}-\mathrm{vWf}$ was analyzed by SDS-agarose electrophoresis (33) followed by autoradiography. For further quantitation of the multimeric distribution of ${ }^{125} \mathrm{I}-\mathrm{vWf}$, the SDS-agarose gels were subjected to a direct radioactivity scanning (Phosphor Imager; Molecular Dynamics, Sunnyvale, CA).

\section{Binding of $v W f$ to purified $G P I b$}

GP Ib-IX complex was purified from a solubilized platelet suspension. Briefly, a platelet concentrate at $20 \times 10^{6}$ platelets $/ \mu \mathrm{l}$ was frozen and thawed three times and subsequently centrifuged at $17,000 \mathrm{~g}$ for $1 \mathrm{~h}$ at $4^{\circ} \mathrm{C}$. The pellet was resuspended in $10 \mathrm{mM}$ Tris buffer, $\mathrm{pH} 7.4$, containing $1 \mathrm{mM}$ EDTA and $10 \mathrm{mM}$ 3-[(3-cholamidopropyl)dimethylammonio]-1-propanesulfonate (CHAPS) (Sigma Chemical Co.) and kept at $4^{\circ} \mathrm{C}$ for $1 \mathrm{~h}$. After another similar centrifugation step, the supernatant was applied onto a CNBr-activated column to which AP 1 had been coupled. The column was thoroughly washed with $10 \mathrm{mM}$ Hepes buffer, pH 7.4, containing $1 \mathrm{mM}$ EDTA and $2 \mathrm{mM} \mathrm{CHAPS}$ and then proteins were eluted using $2 \mathrm{M} \mathrm{KSCN}$ in the same buffer. After extensive dialysis against Hepes buffer, GP Ib was coated to microtiter plates at a final concentration of $2 \mu \mathrm{g} / \mathrm{ml}$ overnight at $4^{\circ} \mathrm{C}$. Plates were blocked with $1 \%$ BSA. Purified $\mathrm{vWf}$ at a final concentration of 20 $\mu \mathrm{g} / \mathrm{ml}$, preincubated with either $50 \mu \mathrm{g} / \mathrm{ml} \mathrm{1C1E7} \mathrm{or} \mathrm{7C7} \mathrm{(irrelevant}$ $\mathrm{mAb}$ ), was applied to the wells in the presence of different concentrations of ristocetin and incubated at room temperature for $2 \mathrm{~h}$. After the appropriate washing steps, horseradish peroxidase (HRP)-conjugated, polyclonal anti-vWf antibody (Dako, Copenhagen, Denmark) was applied for $1 \mathrm{~h}$. Color was developed according to the standard ELISA technology. 


\section{Binding of ${ }^{125} I-v W f$ to heparin}

Binding of ${ }^{125} \mathrm{I}-\mathrm{vWf}$ to heparin-Sepharose (Pharmacia LKB Biotechnology Inc.) was performed essentially as described by Fujimura et al. (34). Heparin-Sepharose beads at a final concentration of $1.25 \%$ in $0.02 \mathrm{M}$ Tris buffer, $\mathrm{pH} 6.0$, were incubated with $2.5 \mu \mathrm{g} / \mathrm{ml}^{125} \mathrm{I}-\mathrm{vWf}$ for $30 \mathrm{~min}$ at room temperature. ${ }^{125} \mathrm{I}-\mathrm{vWf}$ was preincubated with increasing concentrations of $1 \mathrm{ClE} 7$. Bound ligand was separated on a $20 \%$ sucrose cushion as mentioned above and the tube tips were amputated and radioactivity was measured. Nonspecific binding was determined in the presence of $10 \mathrm{mg} / \mathrm{ml}$ heparin sodium salt (Kabivitrum, Stockholm, Sweden ).

\section{Binding of $v W f$ to collagen}

The assay was performed essentially as previously described by Lawrie et al. (35). Briefly, calf skin collagen type I (Sigma Chemical Co.) was dissolved in $0.1 \mathrm{M}$ acetic acid and dialyzed overnight at $4^{\circ} \mathrm{C}$ against 67 $\mathrm{mM}$ phosphate buffer, $\mathrm{pH} 7.2$. Microtiter plates were coated for $18 \mathrm{~h}$ at $37^{\circ} \mathrm{C}$ with $100 \mu \mathrm{l}$ of collagen at a final concentration of $50 \mu \mathrm{g} / \mathrm{ml}$; and then the plates were blocked with $1 \%$ BSA for $1 \mathrm{~h} .100 \mu \mathrm{l}$ of a 1:50 dilution of normal plasma was preincubated with $100 \mu \mathrm{l} 1 \mathrm{ClE} 7$ at a final concentration of $50 \mu \mathrm{g} / \mathrm{ml}$ for $30 \mathrm{~min}$ at $37^{\circ} \mathrm{C}$ and $180 \mu \mathrm{l}$ of this incubation mixture was applied to the wells for $2 \mathrm{~h}$ at $37^{\circ} \mathrm{C}$. The bound vWf was measured by an ELISA using horseradish peroxidase-conjugated polyclonal rabbit anti-vWf antibody (Dako).

\section{Quantitation of binding of 1C1E7 to $v W f$}

mAb 1 C1E7 was labeled with $\mathrm{Na}{ }^{125} \mathrm{I}$ as above. A constant amount of $\mathrm{vWf}(60 \mu \mathrm{g})$ was incubated at room temperature for $30 \mathrm{~min}$ with increasing amounts of ${ }^{125} \mathrm{I}-1 \mathrm{C} 1 \mathrm{E} 7$, ranging between a 0.625 and 18 molar ratio to $\mathrm{vWf}$ monomer $(270 \mathrm{kD})$. $\mathrm{vWf}$ and the associated radioactivity was separated from free ${ }^{125} \mathrm{I}-1 \mathrm{C} 1 \mathrm{E} 7$ on a Sepharose CL $4 \mathrm{~B}$ column. The eluted fractions were measured for radioactivity in a gamma counter and protein concentrations were determined by the Bradford method. The actual amount of ${ }^{125}$ I-1C1E7 associated with vWf could therefore be calculated and a binding curve and Scatchard plot could be constructed.

\section{Digestion of $v W f$ with proteolytic enzymes}

Digestion with Staphylococcus aureus V8 protease (Sigma Chemical Co.) was carried out essentially as described (5). Purified vWf in TBS, $\mathrm{pH} 7.4$, at 1.0 to $1.5 \mathrm{mg} / \mathrm{ml}$ was incubated at $37^{\circ} \mathrm{C}$ with $\mathrm{V} 8$ protease at a final concentration of $36 \mathrm{U} / \mathrm{ml}$ for the indicated period of time. The digestion was terminated by adding diisopropyl fluorophosphate (DFP) in TBS at a final concentration of $24 \mathrm{mM}$.

Trypsin. Tryptic digestion of $\mathrm{vWf}$ was performed according to the method of Fujimura et al. (14). Purified vWf in $0.1 \mathrm{M} \mathrm{NH}_{4} \mathrm{HCO}_{3}$ buffer, $\mathrm{pH} 7.9$, at $1.0 \mathrm{mg} / \mathrm{ml}$ was incubated at $37^{\circ} \mathrm{C}$ with L-1-tosylamide-2-phenylethyl chloromethyl ketone (TPCK)-treated trypsin (Sigma Chemical Co.) at an enzyme/substrate ratio of 1:50 (wt/wt) for $2 \mathrm{~h}$. The digestion was stopped by adding DFP at a final concentration of $10 \mathrm{mM}$. The fragment of $\mathrm{vWf}$ reacting with $1 \mathrm{C} 1 \mathrm{E} 7$ was isolated by an immunoaffinity gel filtration using $\mathrm{CNBr}$-activated Sepharose to which mAb 1C1E7 was coupled. After passing the digestion mixture through the column, it was extensively washed with TBS, pH 7.4, and the weakly bound proteins were eluted using $0.5 \mathrm{M} \mathrm{LiCl}$ in TBS. The specifically bound fragment was eluted using $3.0 \mathrm{M} \mathrm{NaSCN}$ in TBS.

Plasmin. Plasmin digestion of $\mathrm{vWf}$ was performed according to

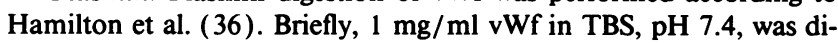
gested with plasmin $\left(1.6 \%\right.$ of vWf by weight) at $37^{\circ} \mathrm{C}$ for $4 \mathrm{~h}$. The reaction was stopped by the addition of $100 \mathrm{U}$ aprotinin $/ \mathrm{ml}$. The plasmic or tryptic fragments of vWf with which 1C1E7 reacted were detected in SDS-PAGE followed by Western blotting.

\section{Purification and characterization of the $34-k D$ plasmic peptide of $v W f$}

This was performed essentially as described (36). $5.5 \mathrm{mg}$ purified vWf in TBS, pH 7.4, was digested with plasmin (see above) for $4 \mathrm{~h}$. After stopping the reaction, the final incubation mixture was lyophilized and dissolved in $2 \mathrm{ml}$ of $4 \mathrm{M}$ guanidine- $\mathrm{HCl}$. This protein solution was gel filtered on a Sepharose CL 4B column in $0.05 \mathrm{M}$ Tris buffer, containing $4 \mathrm{M}$ guanidine- $\mathrm{HCl}$ and $0.15 \mathrm{M} \mathrm{NaCl}, \mathrm{pH}$ 7.4. Further chromatography of the appropriate protein peak was performed on Sephacryl S-200 (Pharmacia LKB Biotechnologies Inc.) in the same buffer. The final pool was dialyzed against TBS and further purified on an immunoaffinity $1 \mathrm{C} 1 \mathrm{E} 7-\mathrm{CNBr}-\mathrm{Sepharose}$ column as described above. The eluted protein was concentrated using microconcentrators (Centricon-10; Amicon Corp. Scientific Sys. Div., Danvers, MA) and extensively dialyzed against $0.1 \mathrm{M}$ acetic acid.

Amino-terminal sequence analysis was done on a protein/peptide sequencer (model 477A; Applied Biosystems, Inc., Foster City, CA).

\section{Investigation of a possible conformational change of $v W f$} caused by 1 CIE7

$100 \mu \mathrm{g}$ purified $\mathrm{vWf}$ was preincubated with $140 \mu \mathrm{g} 1 \mathrm{CIE} 7$ or the same amount of an irrelevant $\mathrm{mAb}$ (7C7) for $30 \mathrm{~min}$ at room temperature. Then TPCK-treated trypsin was added at an enzyme / substrate ratio of 1:100 for $15 \mathrm{~min}$. The reaction was stopped by adding DFP to a final concentration of $10 \mathrm{mM}$. SDS-PAGE (4-16\% gradient) and Western blot were performed. The nitrocellulose membranes were developed using a panel of our own anti-vWf mAbs (82D6A3, 2B1D6, 76E7H7, 4 H1D7) or a rabbit polyclonal antibody (Dako).

\section{Measurement of intracellular $\mathrm{Ca}^{2+}$ in platelets}

Intracellular $\mathrm{Ca}^{2+}$ measurements were performed essentially according to Rink and Sage (37). Briefly, blood was taken on 1/6 vol of acid citrate dextrose anticoagulant, PRP was prepared, and $100 \mu \mathrm{M}$ aspirin was added. Platelets in PRP were then loaded with $2 \mu \mathrm{M}$ Fura-2/AM (Calbiochem Corp.) for $45 \mathrm{~min}$ at room temperature. Platelets were separated by gel filtration on a Sepharose 2B column, equilibrated with Hepes-buffered saline with the following composition (mM): 145 $\mathrm{NaCl}, 5 \mathrm{KCl}, 1 \mathrm{MgCl}_{2}, 0.5 \mathrm{Na}_{2} \mathrm{HPO}_{4}, 10$ Hepes, 5 glucose, pH 7.55. Platelet count was adjusted to $5-7 \times 10^{7} / \mathrm{ml}$. Extracellular calcium concentration was adjusted by addition of $\mathrm{CaCl}_{2}$ as required. $\mathrm{Ca}^{2+}$ measurements were carried out under continuous stirring at $37^{\circ} \mathrm{C}$ in a $\mathrm{LS}$ 50 spectrophotometer (model LS 50; The Perkin-Elmer Corp., Norwalk, CT). Fura-2 fluorescence was measured with excitation at dual wavelength ( 340 and $380 \mathrm{~nm}$ ) and emission at $510 \mathrm{~nm}$.

\section{Results}

Platelet aggregation studies. Two mAbs, 1C1E7 and 2B1D6 (both being IgG2a), increased ristocetin-induced platelet aggregation (RIPA) in plasma. 1C1E7 was more potent than 2B1D6 and was therefore selected for further investigation. Other mAbs directed against either vWf or other proteins had no such effect. 1C1E7 had no influence on platelet aggregations when other inducers such as collagen, ADP, arachidonic acid, or epinephrine were used (data not shown). Furthermore, when 1C1E7 was incubated with PRP obtained from a patient with severe type III von Willebrand's disease, we could not observe aggregation upon addition of ristocetin. 1C1E7 did not induce platelet aggregation when ristocetin was not added.

By increasing the antibody concentration, a dose-dependent increase of the initial slope of the aggregation/agglutination curves induced by ristocetin was found, plateauing above an antibody concentration of $25 \mu \mathrm{g} / \mathrm{ml}$. The enhancing effect was most pronounced at lower concentrations of ristocetin and $0.7 \mathrm{mg} / \mathrm{ml}$ already was sufficient to induce full platelet aggregation, whereas in normal PRP $\geq 1.0-1.2 \mathrm{mg} / \mathrm{ml}$ ristocetin is required. Fig. 1 summarizes the effect of ristocetin and 1C1E7 on platelet aggregation, showing the dose response to increas- 


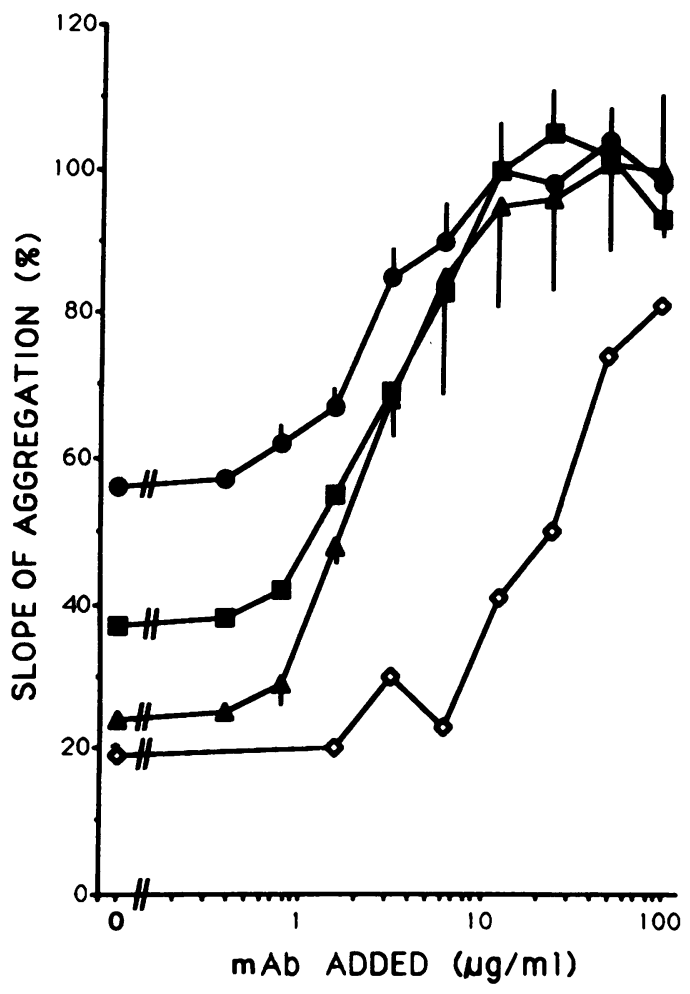

Figure 1. Dose-dependent stimulating effect of 1C1E7 or 1C1E7 Fab on platelet aggregation in PRP at different ristocetin concentrations. Filled symbols represent aggregations (mean \pm SEM; $n=4)$ in the presence of $1 \mathrm{ClE} 7$ at $1.0 \mathrm{mg} / \mathrm{ml}$ (circles), $0.9 \mathrm{mg} / \mathrm{ml}$ (squares), and $0.8 \mathrm{mg} / \mathrm{ml}$ (triangles) ristocetin. Open symbols represent aggregations (mean of two) in the presence of $1 \mathrm{ClE} 7 \mathrm{Fab}$ at $0.8 \mathrm{mg} / \mathrm{ml}$ ristocetin. The maximal velocity of the aggregation is expressed as percentage of the one, obtained at $1.0 \mathrm{mg} / \mathrm{ml}$ ristocetin and $12.5 \mu \mathrm{g} / \mathrm{ml}$ $1 \mathrm{C} 1 \mathrm{E} 7$. The enhancing effect of $1 \mathrm{C} 1 \mathrm{E} 7$ was already statistically significant at $1.5 \mu \mathrm{g} / \mathrm{ml}$ for every ristocetin concentration used.

ing antibody concentrations as well as the markedly enhanced response to low ristocetin concentrations.

Since platelet aggregation in PRP is rather complex, we repeated these experiments using washed platelets. Here we also observed an increase in vWf activity (two- to threefold), measured as RiCoF, when either diluted plasma or purified vWf was preincubated with 1C1E7 (data not shown).

ASvWf does not require ristocetin to induce platelet aggregation in PRP (38). The effect of 1C1E7 on ASvWf-induced platelet aggregation was also investigated. A fixed concentration of ASvWf, preincubated with increasing concentrations of $1 \mathrm{C} 1 \mathrm{E} 7$, induced a dose-dependent increase of platelet aggregation in PRP similar to that observed with RIPA (data not shown).

The influence of an inhibitory antiplatelet GP IIb/IIIa $\mathrm{mAb}(16 \mathrm{~N} 7 \mathrm{C} 2$ ) on the RIPA and ASvWf-induced platelet aggregation was also evaluated. As shown in Fig. 2, despite complete inhibition of GP IIb/IIIa receptors, we could still induce an increased aggregation when 1C1E7 was added, using either a low concentration of ristocetin or ASvWf. This suggests a heightened interaction between vWf and GP Ib. Indeed, using AP 1, an inhibitory anti-GP Ib mAb, we could completely inhibit both the RIPA or ASvWf-induced platelet aggregations, whether 1C1E7 or no 1C1E7 was present (data not shown).

Binding of ${ }^{125} I-v W f$ and ${ }^{125} I-A S v W f$ to platelets. The affinity of radiolabeled and unlabeled $\mathrm{vWf}$ for platelets was found to be similar (data not shown). Time course experiments showed that, after addition of ristocetin, binding of ${ }^{125} \mathrm{I}-\mathrm{vWf}$ to platelets reached a plateau between 20 and $30 \mathrm{~min}$ and remained at the same level for $60 \mathrm{~min}$ (data not shown).

Binding experiments were performed using increasing concentrations of ${ }^{125} \mathrm{I}-\mathrm{vWf}$ (Fig. 3). Binding of ${ }^{125} \mathrm{I}-\mathrm{vWf}$ to ristocetin-stimulated platelets was saturable. In the presence of $1 \mathrm{C} 1 \mathrm{E} 7$, binding of ${ }^{125} \mathrm{I}-\mathrm{vWf}$ was significantly increased. The anti-GP IIb/IIIa antibody had no influence on the binding of normal vWf to platelets, but it could partially inhibit the increased binding of $\mathrm{vWf}$ induced by $1 \mathrm{C} 1 \mathrm{E} 7$, a phenomenon that was already statistically significant at $1 \mu \mathrm{g} / \mathrm{ml} \mathrm{vWf}$ added, at which stage only a limited number of GP Ib receptors were occupied. These findings therefore show that 1C1E7 induces an increased binding to GP Ib accompanied by an additional binding to GP IIb/IIIa, an observation that has never been reported previously with ristocetin alone. However, using the mAb-inhibiting vWf binding to GP Ib (AP 1), we could completely inhibit the binding of vWf to platelets, whether 1C1E7 or no $1 \mathrm{CIE} 7$ was present, suggesting that binding of vWf to GP Ib obligatorily precedes the binding to GP IIb/IIIa.

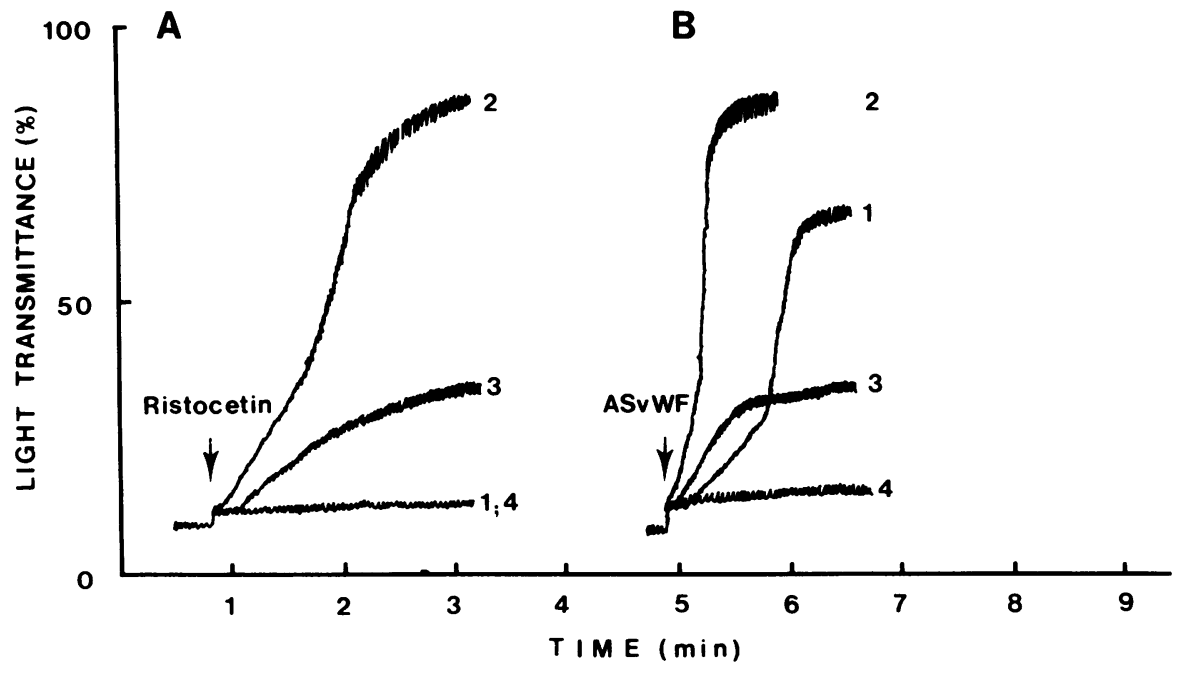

Figure 2. $(A)$ Effect of an anti-GP IIb/IIIa $\mathrm{mAb}(16 \mathrm{~N} 7 \mathrm{C} 2)$ on ristocetin and $(B)$ asialo vWf induced aggregation in the presence or absence of 1C1E7. The final concentration of ristocetin was $0.7 \mathrm{mg} / \mathrm{ml}$ whereas that of the asialo vWf was $26 \mu \mathrm{g} /$ ml. 1C1E7 was preincubated with PRP or ASvWf for $30 \mathrm{~min}$ at room temperature, and 16 N7C2 was added to the PRP $10 \mathrm{~min}$ before the addition of the inducer. Tracing 1 , control; tracing $2,20 \mu \mathrm{g} / \mathrm{ml} 1 \mathrm{C} 1 \mathrm{E} 7$; tracing $3,20 \mu \mathrm{g} / \mathrm{ml} 1 \mathrm{ClE} 7$ and $20 \mu \mathrm{g} / \mathrm{ml}$ 16N7C2; tracing 4, $20 \mu \mathrm{g} / \mathrm{ml} \mathrm{16N7C2.}$ 

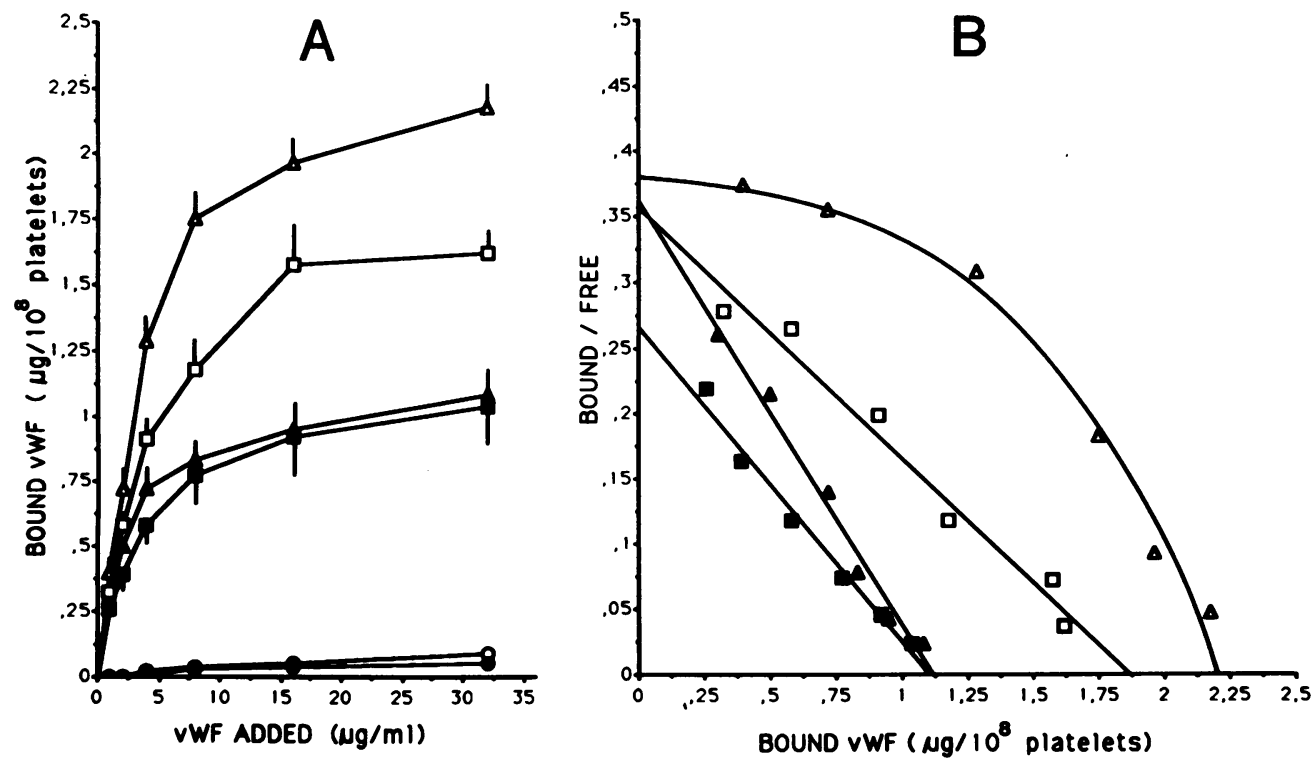

Figure 3. $(A)$ Dose-dependent specific binding of ${ }^{125} \mathrm{I}-\mathrm{vWf}$ to washed platelets after addition of $1.0 \mathrm{mg} / \mathrm{ml}$ ristocetin and $(B)$ Scatchard plot analysis of the binding curves. ${ }^{125} \mathrm{I}-\mathrm{vWf}$ was preincubated with $25 \mu \mathrm{g} / \mathrm{ml}$ 1C1E7 or with a comparable amount of buffer for $30 \mathrm{~min}$ at room temperature. $16 \mathrm{~N} 7 \mathrm{C} 2$ (anti-GP IIb/IIIa mAb) or AP 1 (anti-GP Ib mAb) at a final concentration of $20 \mu \mathrm{g} / \mathrm{ml}$ was incubated with the platelet suspension for $10 \mathrm{~min}$ at room temperature before the addition of ${ }^{125} \mathrm{I}-\mathrm{vWf}$ and ristocetin. Control (filled triangles); control +16 N7C2 (filled squares); control + AP 1 (filled circles); 1C1E7 (open triangles); 1C1E7 +16 N7C2 (open squares); 1C1E7 + AP 1 (open circles). Mean \pm SEM is shown $(n=6)$.
Scatchard plot analysis of these data showed that in control conditions there is indeed only one class of binding sites, i.e., GP Ib (Fig. $3 B$ ). When binding of vWf-1C1E7 complex to GP IIb/IIIa was inhibited by 16 N7C2, the Scatchard graph also was linear and parallel to the control curve, showing that more $\mathrm{vWf}$ could bind to GP Ib but the affinity of vWf towards the receptor remained the same. On the contrary, the Scatchard graph obtained with vWf modified by 1C1E7 was an upward convex ellipse, which is in agreement with the findings that in this situation there are two different binding sites for $\mathrm{vWf}$, namely GP Ib and GP IIb/IIIa. The shape of the curve suggests a positive cooperativity between the two binding sites, a hypothesis confirmed using Hill plot analysis. Indeed, significant differences $(P<0.01)$ were found between the slopes of the Hill plot curves, indicating that, when vWf is modified by $1 \mathrm{C} 1 \mathrm{E} 7$, binding to GP Ib facilitates vWf binding to its second receptor, GP IIb/IIIa. Because of the heterogeneity in the molecular weight of the $\mathrm{vWf}$ multimers, neither an accurate $K_{\mathrm{d}}$ expressed in molarity nor the precise number of binding sites can be calculated. Therefore the amount of $\mathrm{vWf}$ bound was expressed in micrograms $/ 10^{8}$ platelets.

Binding of ${ }^{125} \mathrm{I}-\mathrm{vWf}$ to platelets in control conditions essentially increased in a linear relation with the ristocetin concentration up to $1.5 \mathrm{mg} / \mathrm{ml}$; this was not influenced by $20 \mu \mathrm{g} / \mathrm{ml}$ 16 N7C 2 . In contrast, when vWf was preincubated with $1 \mathrm{C} 1 \mathrm{E} 7$, the binding was significantly increased and already plateaued at $0.6 \mathrm{mg} / \mathrm{ml}$ ristocetin. However, in the absence of ristocetin, 1C1E7 did not induce binding of ${ }^{125} \mathrm{I}-\mathrm{vWf}$ to platelets.

Binding of ${ }^{125} \mathrm{I}-\mathrm{vWf}$ to thrombin-stimulated washed platelets was also investigated. These data, together with the Scatchard analysis, are shown in Fig. 4. Binding of ${ }^{125} \mathrm{I}-\mathrm{vWf}$ was saturable and maximal binding was reached at $1.50 \pm 0.28 \mu \mathrm{g} /$ $10^{8}$ platelets $(n=3)$ in control conditions. The maximal binding of ${ }^{125} \mathrm{I}-\mathrm{vWf}$ after incubation with 1C1E7 was increased to $2.53 \pm 0.36 \mu \mathrm{g} / 10^{8}$ platelets $(n=3, P<0.05)$. Scatchard analysis showed that the curves were parallel. mAb against $\mathrm{GP} \mathrm{Ib}$ (AP 1) did not influence the binding of $\mathrm{vWf}$ to thrombin-stimulated platelets, whether 1C1E7 or no $1 \mathrm{C} 1 \mathrm{E} 7$ was present.
However, the anti-GP IIb/IIIa mAb completely inhibited the binding of normal or 1C1E7-modified vWf.

The effect of our stimulating antibody on the binding of ${ }^{125}$ I-ASvWf also was studied. Binding of a fixed dose of ASvWf was increased in a dose-dependent manner by 1C1E7 (data not shown).

Binding of $v W f$ to purified GP Ib. mAb 1C1E7 induced a $1.82 \pm 0.18$-fold increase of binding of $\mathrm{vWf}$ to purified platelet GP Ib in the presence of $0.2 \mathrm{mg} / \mathrm{ml}$ ristocetin $(n=3)$, using an ELISA-type assay (see Methods).

Platelet aggregations and binding assays in the presence of the Fab fragment of $1 C 1 E 7$. As shown in Fig. 1, in the presence of Fab fragments, RIPA could be increased in a dose-dependent manner, as with intact IgG. However, higher concentrations were needed to achieve the same enhancing effect. A significantly increased binding of ${ }^{125} \mathrm{I}-\mathrm{vWf}$ to platelets in plasma could be observed in the function of the concentration of $\mathrm{Fab}$ fragment (Fig. $5 \mathrm{~A}$ ). The Fab preparations used in these experiments were essentially free of intact IgG and $F\left(a b^{\prime}\right)_{2}$ fragments as shown in the inset. Comparing the slope of the aggregations and the amount of bound vWf to platelets, both obtained at increasing concentrations of 1C1E7 Fab, a significant correlation $(r=0.97)$ could be demonstrated (Fig. $5 B$ ).

Multimeric analysis of bound ${ }^{125}$ I- $\nu W f$ to platelets. Fig. 6 shows the distribution of the different molecular weight multimers of either ${ }^{125} \mathrm{I}-\mathrm{vWf}$ specifically bound to the platelet surface or that of the ${ }^{125}$ I-ligand used in the assays. A slight increase in the binding of the higher multimers to the platelet surface could already be observed in the presence of ristocetin alone, which is in line with previous observations (39). Furthermore, as already suggested by the results of the binding assays in the presence of $1 \mathrm{C} 1 \mathrm{E} 7$, the binding of the intermediate and high molecular weight multimers was even more increased using either ristocetin or thrombin as inducer.

Effect of $1 C I E 7$ on other $v W f$ functions than the GP Ib-or GP IIb/IIIa-binding domains. The mAb 1C1E7 had no influence on the binding of vWf to either heparin or collagen (data not shown). 

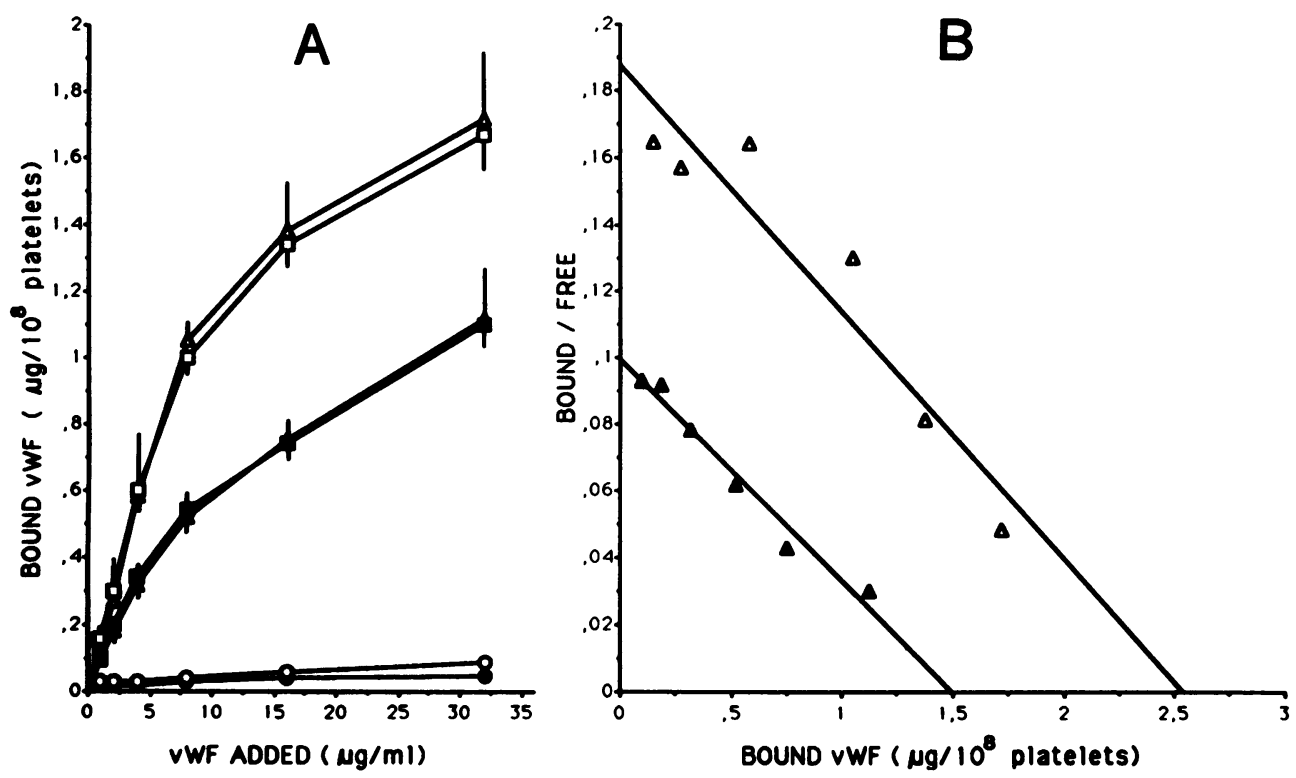

Figure 4. ( $A$ ) Dose-dependent specific binding of ${ }^{125} \mathrm{I}-\mathrm{vWf}$ to thrombin-stimulated washed platelets and $(B)$ Scatchard plot analysis of the binding curves. ${ }^{125} \mathrm{I}-\mathrm{vWf}$ was preincubated with $25 \mu \mathrm{g} / \mathrm{ml} 1 \mathrm{C} 1 \mathrm{E} 7$ or with a comparable amount of buffer for 30 min at room temperature. 16N7C2 (anti-GP IIb/IIIa mAb) or AP 1 (anti-GP Ib mAb) at a final concentration of $20 \mu \mathrm{g} / \mathrm{ml}$ was preincubated with the platelet suspension for $10 \mathrm{~min}$ at room temperature before the addition of ${ }^{125} \mathrm{I}-\mathrm{vWf}$ and $0.5 \mathrm{U} / \mathrm{ml}$ thrombin. Control (filled triangles); control + 16N7C2 (filled circles); control + AP 1 (filled squares); 1C1E7 (open triangles); 1C1E7 + 16N7C2 (open circles); 1C1E7 + AP 1 (open squares). Mean $\pm \mathrm{SD}$ is shown ( $n$ $=3$ ).
Quantitation of binding of $1 C 1 E 7$ to $v W f$. As shown in Fig. $7 \mathrm{~A}$, binding of $1 \mathrm{ClE} 7$ to $\mathrm{vWf}$ is saturable. Above a $5: 1 \mathrm{molar}$ ratio of $1 \mathrm{C} 1 \mathrm{E} 7 / \mathrm{vWf}$ monomer, the binding curve reaches a plateau. Scatchard analysis (Fig. $7 \mathrm{~B}$ ) showed one class of binding sites with a $K_{d}$ of $4.3 \times 10^{-10} \mathrm{M}$. At saturation, nearly $1 \mathrm{~mol}$ 1C1E7 bound per mol vWf monomer. A 5:1 molar ratio of $1 \mathrm{C} 1 \mathrm{E} 7 / \mathrm{vWf}$ monomer corresponds to $\sim 25 \mu \mathrm{g} 1 \mathrm{ClE} 7 / \mathrm{ml}$ of plasma, the concentration used in most experiments described above.

Epitope mapping of $v W f$ using proteolytic enzymes. Digestion of vWf with Staphylococcus V8 protease resulted in two major fragments of 170 and $110 \mathrm{kD}$ under reducing conditions, as reported previously (5). As shown in Fig. 8, the $\mathrm{NH}_{2}$-terminal $170-\mathrm{kD}$ band was recognized by $1 \mathrm{ClE} 7$ in a Western blot.

After plasmin digestion of $\mathrm{vWf}$ and analysis under either nonreducing or reducing conditions, the smallest fragment recognized by 1C1E7 had a molecular mass of $34 \mathrm{kD}$. However, the reduction of the supposed intrachain disulphide bridges obviously reduced the affinity of the antibody for this fragment. Moreover, a 170-kD band was detected by 1C1E7 under reducing conditions. Plasmin is known to cleave $\mathrm{vWf}$ at a position close to the one split by the V8 protease. This $170-\mathrm{kD}$ fragment therefore is most probably nearly identical to the one obtained after V8 protease digestion.

As shown in Fig. 9, the smallest tryptic fragment recognized by $1 \mathrm{ClE} 7$ was a doublet of 34-36 kD under nonreducing conditions. After reduction several smaller bands, which were no longer recognized by $1 \mathrm{C1E7}$, appeared in the SDS-PAGE.

Amino-terminal sequencing. This was performed on the isolated 34-kD plasmic fragment, which revealed two sequences of 15 amino acids each. The major sequence (2/3) was found to be identical to the amino terminus of the mature $\mathrm{vWf}$ subunit and the other $(1 / 3)$ started at residue 264 , implying only a partial digestion of the Lys 263-Val 264 bond.

A possible conformational change caused by $1 C 1 E 7$. Several differences could be identified between the tryptic fragments of vWf that had been preincubated with either $1 \mathrm{C} 1 \mathrm{E} 7$ or

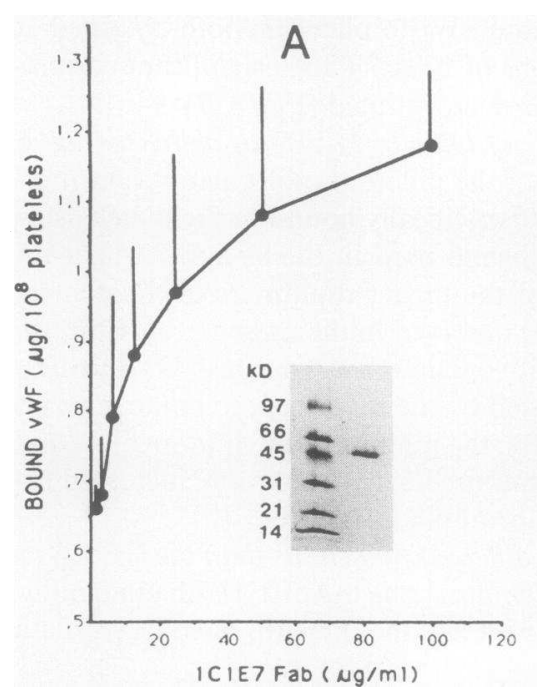

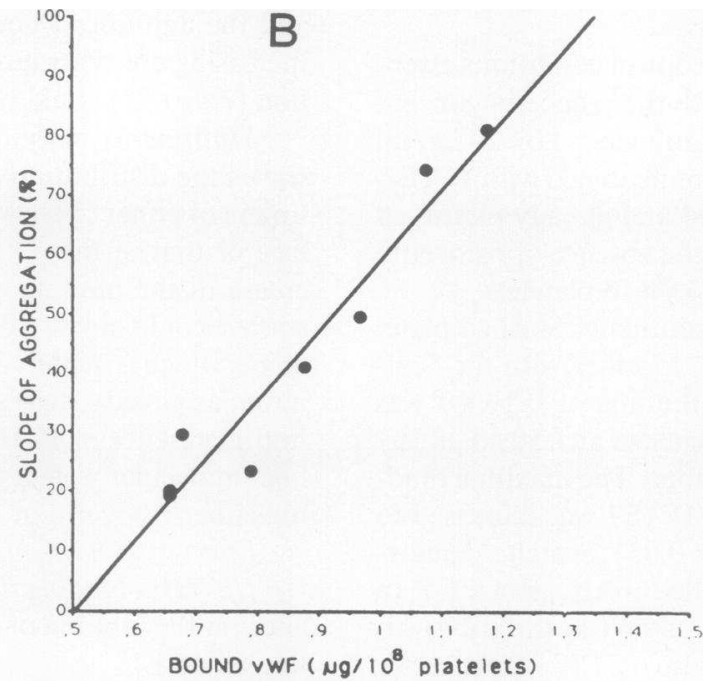

Figure 5. ( $A$ ) Dose-dependent specific binding of ${ }^{125} \mathrm{I}-\mathrm{vWf}$ to platelets (mean \pm SD; $n=4$ ) after addition of $0.8 \mathrm{mg} / \mathrm{ml}$ ristocetin in the presence of the Fab fragment of 1C1E7 and (B) the correlation between the increasing amount of platelet-associated vWf and the maximal velocity of the aggregation shown in Fig. 1. (Inset) The purity of the Fab fragment is demonstrated on SDS-PAGE (10-15\% gradient gel, nonreducing conditions). 


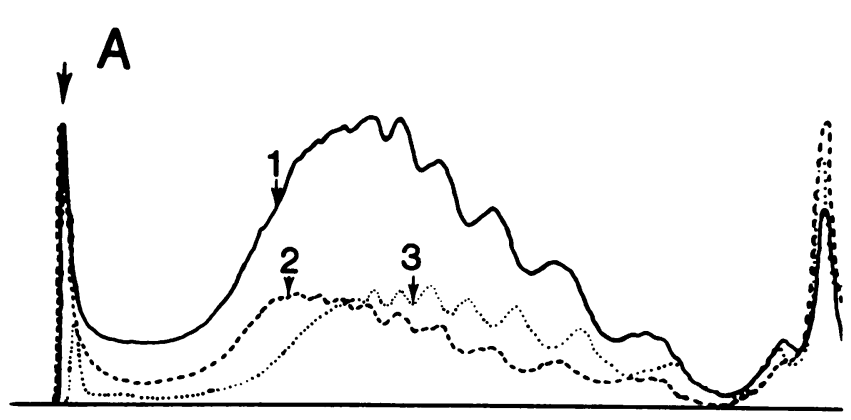

B

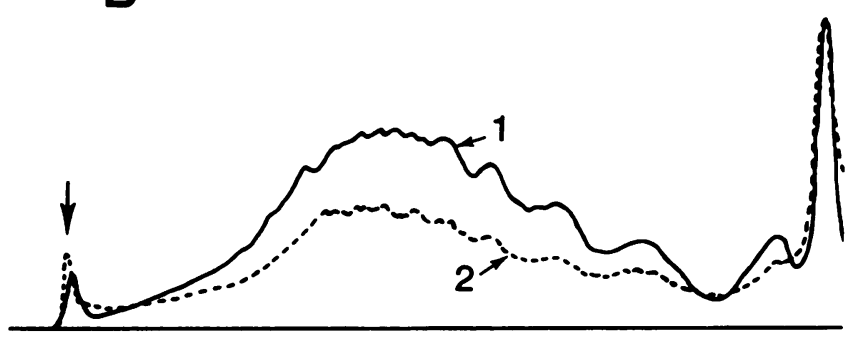

Figure 6. Multimeric analysis of ligand $\left(\mathrm{A}_{3}\right)$ or bound ${ }^{125} \mathrm{I}-\mathrm{vWf}$ to platelets in the presence $\left(A_{1} B_{1}\right)$ or absence $\left(A_{2} B_{2}\right)$ of mAb 1C1E7, after addition of $(A) 1.0 \mathrm{mg} / \mathrm{ml}$ ristocetin or $(B) 0.5 \mathrm{U} / \mathrm{ml}$ thrombin. The direct radioactivity scans of the SDS-agarose gels are shown. Arrows on the left indicate the application site of the samples.

an irrelevant murine mAb. The most prominent difference was detected by both a polyclonal antibody and a mAb, 82D6A3. In control conditions a tryptic fragment with a molecular mass of $137 \mathrm{kD}$ could be observed, whereas trypsin digestion resulted in a fragment of $115 \mathrm{kD}$ when $\mathrm{vWf}$ had been preincubated with $1 \mathrm{C} 1 \mathrm{E} 7$. This would suggest a different cleavage site than in the control. Minor differences were also detected using the other mAbs.

Changes in platelet intracellular $\mathrm{Ca}^{2+}$ levels induced by the complex of asialo $v W f$ and $1 C 1 E 7$. A significant and rapid rise of intracellular $\mathrm{Ca}^{2+}$ was detected in platelets stimulated with
$30 \mu \mathrm{g} / \mathrm{ml}$ ASvWf that had been preincubated with $50 \mu \mathrm{g} / \mathrm{ml}$ 1C1E7 (Fig. 10). These results were obtained in the presence of $1 \mathrm{mM}$ extracellular $\mathrm{Ca}^{2+}$ concentration, whereas without addition of extracellular $\mathrm{Ca}^{2+}$ the intraplatelet $\mathrm{Ca}^{2+}$ increase was less pronounced (data not shown). When the same amount of ASvWf was added alone to the platelet suspension, we could not observe any increase in the intracellular $\mathrm{Ca}^{2+}$ level.

\section{Discussion}

A number of mAbs have been described that react with different domains of vWf and inhibit the function of that particular region $(13,14,40,41)$. As far as we know, however, there is only one report on two mouse mAbs that stimulate vWf function, i.e., they increase the rate of $\mathrm{vWf}$-dependent platelet agglutination in the presence of ristocetin. However, increased binding of vWf to platelets due to these mAbs was not demonstrated in that study (42).

We have developed two mAbs that significantly increased the RIPA, RiCoF activity, and ASvWf-induced platelet aggregation. 1C1E7 was selected for extensive investigation. We found an increased responsiveness of platelets to ristocetin in the presence of the antibody. The enhancing effect of 1C1E7 on platelet aggregation was dose dependent. From platelet aggregation experiments, where GP IIb/IIIa receptors were inhibited by $16 \mathrm{~N} 7 \mathrm{C} 2$, we already could conclude that $1 \mathrm{C} 1 \mathrm{E} 7 \mathrm{in}$ duces an increased vWf-GP Ib interaction, which could be completely inhibited by an anti-GP Ib mAb.

Ristocetin-induced binding of radiolabeled $\mathrm{vWf}$ to platelets confirmed the findings of the aggregation studies. Unlike a previous report (42), we could demonstrate an increased binding of $\mathrm{vWf}$ to platelets with our antibody upon either ristocetin or thrombin stimulation.

Analysis of the vWf binding to ristocetin-stimulated platelets revealed that in control conditions vWf bound to only one receptor, i.e., GP Ib, which is in agreement with previous reports $(28,43)$. However, when $\mathrm{vWf}$ was incubated with $1 \mathrm{C} 1 \mathrm{E} 7$, it was modified in such a way that its binding to GP Ib was increased; this was followed by an additional binding of

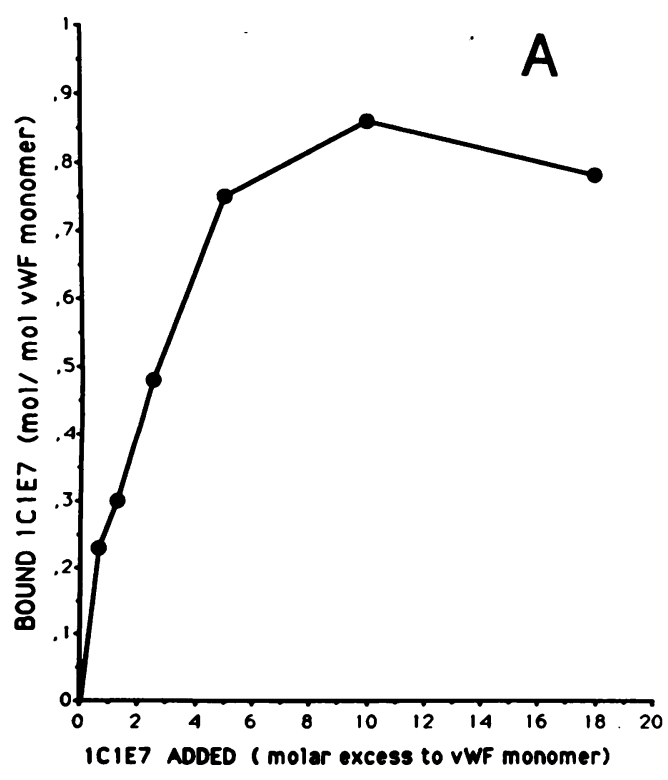

Figure 7. ( $A$ ) Dose-dependent binding of ${ }^{125} \mathrm{I}-1 \mathrm{C} 1 \mathrm{E} 7$ to purified $\mathrm{vWf}$ and $(B)$ Scatchard plot analysis of the binding curve. For details see Methods. 


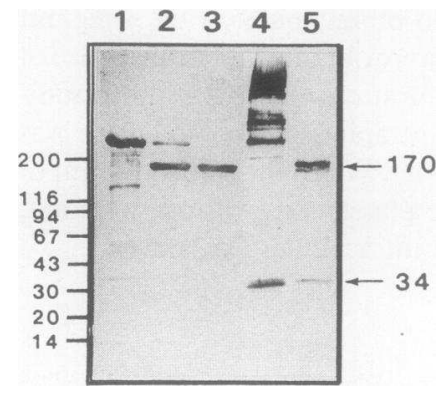

Figure 8 . Immunoreactivity of 1C1E7 with vWf fragments generated by digestion with Staphylococcus aureus V8 protease or plasmin. Fragments were separated by SDS-PAGE (4-16\% gradient slab gel), which was followed by Western blotting. Each lane represents the whole digestion mixture. Lane 1 , undigested $\mathrm{vWf}$ (reduced); lane $2, \mathrm{~V} 8$ protease

digestion after 1 min (reduced); lane 3 , V8 protease digestion after $12 \mathrm{~min}$ (reduced); lane 4, plasmin digestion after $4 \mathrm{~h}$ (nonreduced); lane 5 , plasmin digestion after $4 \mathrm{~h}$ (reduced). The molecular mass $(\mathrm{kD})$ of the $\mathrm{vWf}$ fragments is indicated on the right and that of the standards on the left.

vWf to GP IIb/IIIa. This phenomenon has never been published for ristocetin-induced binding of normal vWf but is known for ASvWf $(32,44)$ and vWf purified from patients with von Willebrand's disease type IIB (45).

In the presence of 1C1E7 and the absence of the anti-GP IIb/IIIa $\mathrm{mAb}$, Scatchard analysis indicated the existence of two binding sites with positive cooperativity (46); binding of the ligand to the first receptor, GP Ib, facilitates the binding to the second, GP IIb/IIIa; indeed, by blocking GP IIb/IIIa, the Scatchard curve became linear again. The Scatchard analysis suggests that more protein bound to the platelets with the same affinity, which would then refer to binding of an identical number of molecules but of higher average molecular weight, as could be demonstrated. The preferential binding of higher molecular weight $\mathrm{vWf}$ could facilitate cross-linking of several GP Ib molecules, which would then result in platelet activation.

Binding of $\mathrm{vWf}$ to thrombin-stimulated platelets, in this case solely to GP IIb/IIIa $(12,28)$, was similarly increased, and Scatchard analysis again showed parallel curves, confirming that 1C1E7 does not influence the affinity of $v W f$ for platelets but induces more binding on a weight basis.

We could observe a similar enhancing effect of 1C1E7 on the functions of ASvWf in platelet aggregations as well as in binding experiments, which suggests that the mechanism of action of 1C1E7 is independent of the sialic acid content of vWf.

The Fab fragment of $1 \mathrm{ClE} 7$ was able to induce a similar modification in $\mathrm{vWf}$ functions as the intact IgG, which would rule out the possibility that the formation of extra large multimers by antibody-induced cross-linking would be the main mechanism of this stimulatory effect. We have three other lines

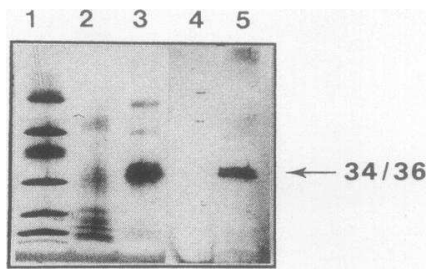

Figure 9. SDS-PAGE (10-15\% gradient slab gel) and Western blotting analysis of a 1Cب1E7 affinity-purified tryptic fragment of vWf. (see Methods). Coomassie blue staining (lanes 2 and 3 ) and Western blot using 1C1E7 (lanes 4 and 5) under reducing (lanes 2 and 4 ) and nonreducing (lanes 3 and 5 ) conditions. Molecular mass standards are run in lane $1(94,67,43,30,20$, and $14 \mathrm{kD})$. The molecular mass of the tryptic fragment is shown on the right.

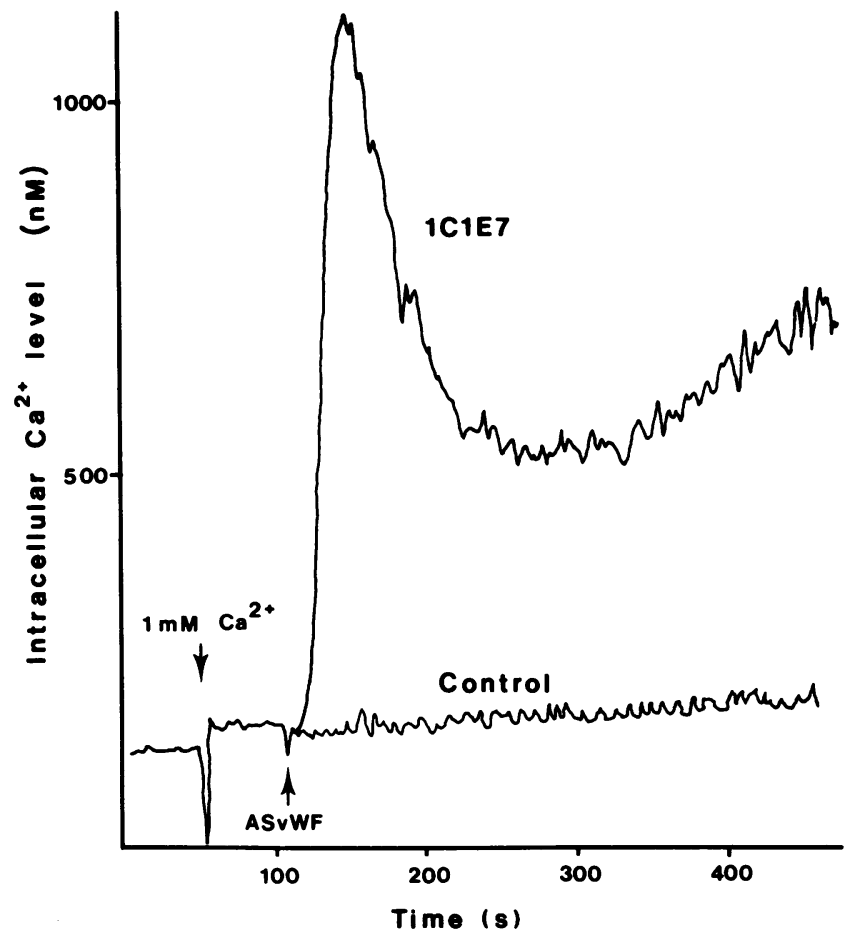

Figure 10. Changes in intracellular $\mathrm{Ca}^{2+}$ levels after stimulation of Fura-2-loaded washed platelets with ASvWf or ASvWf-1C1E7 complex. ASvWf was preincubated with $50 \mu \mathrm{g} / \mathrm{ml}$ of $1 \mathrm{C} 1 \mathrm{E} 7$ or with buffer (control) for $30 \mathrm{~min}$ at room temperature. $1 \mathrm{mM}$ extracellular $\mathrm{Ca}^{2+}$ was added as indicated. ASvWf was added to a final concentration of $30 \mu \mathrm{g} / \mathrm{ml}$. One representative experiment out of four is shown.

of evidence to confirm this statement. First, at saturation conditions, a nearly 1:1 molar ratio between 1C1E7 and vWf monomer could be achieved. Second, in the presence of 1C1E7 and ristocetin, $\mathrm{vWf}$ at concentrations far below those saturating of the GP Ib receptors could already induce platelet activation and exposure of the GP IIb/IIIa receptors. This would imply that mainly qualitative changes in vWf have been induced by the antibody. Third, if the antibody only acted via cross-linking of the multimers, we would not be able to demonstrate an increased binding of the higher multimers to the platelet surface, since the denaturing effect of SDS would break down antibody cross-linked multimers.

The tryptic or plasmic fragments recognized by 1C1E7 were similar to the ones previously described as III-T4 (46) or P34 $(5,36)$. These fragments extend from residue 1 to 272 (III-T4)/298 (P34). The amino-terminal sequencing proved that indeed our tryptic or plasmic fragments are identical to the ones mentioned above. The secondary cleavage site found for plasmin is located between Lys 263 and Val 264 and the putative small peptide fragment $264-298$ is connected to the major fragment via a disulphide bridge between Cys residues 126-268 (47). The amino-terminal region of the vWf subunit is very rich in cysteine residues (48), all of which are involved in intrachain disulphide bridges (47), and the presence of one or more such disulphide bridge(s) seems to be needed for the integrity of the epitope.

1C1E7 therefore interacts with a segment of vWf on which the FVIII-binding site and one of the heparin-binding domains have already been localized (49) and yet it influences the func- 
tion of the GP Ib- and GP IIb/IIIa-binding domains. The GP Ib-binding domain was identified on a $52 / 48-\mathrm{kD}$ tryptic fragment beginning with amino acid residue 449 (18) and the GP IIb/IIIa-binding domain was found close to the carboxy terminus of the subunit (48). The 52/48-kD tryptic fragment binds to platelets without ristocetin (18), whereas the mammalian-expressed fragment showed an increased binding only in the presence of ristocetin $(50)$. These findings could suggest that other portions of the molecule have a modulating effect on the binding of whole vWf to GP Ib. A recent abstract also suggests the existence of a modulatory domain on the native $\mathrm{vWf}(51)$. In the light of these and our findings, we can hypothesize that $1 \mathrm{ClE} 7$ binds to an epitope that plays a modulatory role in vWf function. Indeed, our preliminary data suggest a possible conformational change in vWf after incubation with 1C1E7. Binding of the antibody to $\mathrm{vWf}$ caused an alteration of the proteolytic digestion pattern. This could be caused on the one hand by steric hindrance of the access to a cleavage site or on the other hand by exposure of a new cleavage site due to a conformational change. In the first case, a larger fragment could be expected; in the latter case, a smaller peptide could result. That was observed.

Very little is known about the signal transduction after vWf binding to platelets. Recent data showed that vWf together with ristocetin can cause phospholipase C-dependent breakdown of phosphatidyl inositol bisphosphate, phosphorylation of a 47-kD protein, and an increase in cytosolic $\mathrm{Ca}^{2+}$ level (52), which could be inhibited by an anti-GP Ib but not by an anti-GP IIb/IIIa antibody. We did not observe an increase of intracellular $\mathrm{Ca}^{2+}$ using ASvWf. However, when ASvWf was preincubated with $1 \mathrm{ClE} 7$, a rapid significant rise of intracellular $\mathrm{Ca}^{2+}$ was found. This can be the consequence of purely quantitative changes, i.e., binding of more or larger $\mathrm{vWf}$ to platelet GP Ib. The exact nature of these events remains to be established.

Binding of vWf to the subendothelium would be followed by a conformational change $(1,10)$ resulting in direct binding of the larger multimers to platelet GP Ib and, after platelet activation, to GP IIb/IIIa. The similarity to the modifications induced in vWf by 1C1E7 may suggest that this antibody recognizes a domain of relevance for $\mathrm{vWf}$ physiology.

In conclusion, we report here on a murine mAb against $v W f$ with a unique functional activity. The antibody is directed against an epitope localized on the amino-terminal portion of vWf between residues 1 and 272. The antibody increases the binding of vWf to GP IIb/IIIa of thrombin-stimulated platelets and independently from this phenomenon it also induces an increased binding to GP Ib of ristocetin-stimulated platelets, followed by an additional binding to GP IIb/IIIa. The epitope with which this antibody reacts probably has a general modulatory effect on $\mathrm{vWf}$ function, by improving the presentation of mainly the larger molecular weight multimers.

\section{Acknowledgments}

The authors are very grateful to Dr. J. Vandamme, Rega Institute, University of Leuven, for the $\mathrm{NH}_{2}$-terminal amino acid sequence analysis. The authors also thank Dr. P. J. Declerck, Dr. J. Harsfalvi, and M. Wendt for their technical assistance and helpful advice.

This study was supported by a grant from the Belgian "Nationaal Fonds voor Geneeskundig Wetenschappelijk Onderzoek." Istvan Tornai was also supported by the Soros Foundation, Leuven Research and Development, and the Onderzoeksfonds of the K.U. Leuven.

\section{References}

1. Baruch, D., B. Bahnak, J. P. Girma, and D. Meyer. 1989. von Willebrand factor and platelet function. Bailliere's Clin. Haematol. 2:627-672.

2. Chopek, M. W., J. P. Girma, K. Fujikawa, E. W. Davie, and K. Titani. 1986. Human von Willebrand factor: a multivalent protein composed of identical subunits. Biochemistry. 25:3146-3155.

3. Sixma, J. J., K. S. Sakariassen, N. H. Beeser-Visser, M. Ottenhof-Rovers, and P. A. Bolhuis. 1984. Adhesion of platelets to human artery subendothelium: effect of factor VIII-von Willebrand factor of various multimeric composition. Blood. 63:128-139.

4. Girma, J. P., D. Meyer, C. L. Verweij, H. Pannekoek, and J. J. Sixma. 1987. Structure-function relationship of human von Willebrand factor. Blood. 70:605611 .

5. Fretto, L. J., W. E. Fowler, D. R. McCaslin, H. P. Erickson, and P. A. McKee. 1986. Substructure of human von Willebrand factor. Proteolysis by V8 and characterization of two functional domains. J. Biol. Chem. 261:1567915689.

6. Girma, J. P., M. Kalafatis, G. Pietu, J. M. Lavergne, M. W. Chopek, T. S. Edgington, and D. Meyer. 1986. Mapping of distinct von Willebrand factor domains interacting with platelet GP Ib and GP IIb/IIIa and with collagen using monoclonal antibodies. Blood. 67:1356-1366.

7. Mohri, H., Y. Fujimura, M. Shima, A. Yoshioka, R. A. Houghten, Z. M. Ruggeri, and T. S. Zimmerman. 1988. Structure of the von Willebrand factor domain interacting with glycoprotein Ib. J. Biol. Chem. 263:17901-17904.

8. de Groot, P. G., M. Ottenhof-Rovers, J. A. van Mourik, and J. J. Sixma. 1988. Evidence that the primary binding site of von Willebrand factor that mediates platelet adhesion on subendothelium is not collagen. J. Clin. Invest. 82:6573.

9. Rand, J. H., N. D. Patel, E. Schwartz, S. L. Zhou, and B. J. Potter. 1991. $150-\mathrm{kD}$ von Willebrand factor binding protein extracted from human vascular subendothelium is type VI collagen. J. Clin. Invest. 88:253-259.

10. Bolhuis, P. A., K. S. Sakariassen, H. J. Sander, B. N. Bouma, and J. J. Sixma. 1981. Binding of factor VIII-von Willebrand factor to human arterial subendothelium precedes increased platelet adhesion and enhances platelet spreading. J. Lab. Clin. Med. 97:568-576.

11. Coller, B. S. 1985. Platelet-von Willebrand factor interactions. In Platelet Membrane Glycoproteins. J. N. George, A. T. Nurden, and DR. Phillips, editors. Plenum Publishing Corporation. New York. 215-244.

12. Sadler, J. E. 1991. von Willebrand factor. J. Biol. Chem. 266:2277722780.

13. Meyer, D., H. R. Baumgartner, and T. S. Edgington. 1984. Hybridoma antibodies to human von Willebrand factor. II. Relative role of intramolecular loci in mediation of platelet adhesion to subendothelium. Br. J. Haematol. 57:609-620.

14. Fujimura, Y., Y. Usami, K. Titani, K. Niinomi, K. Nishio, T. Takase, A. Yoshioka, and H. Fukui. 1991. Studies on anti-von Willebrand factor (vWf) monoclonal antibody NMC-4, which inhibits both ristocetin- and botrocetin-induced vWf binding to platelet glycoprotein Ib. Blood. 77:113-120.

15. Tangen, O., and H. J. Berman. 1972. Gel filtration of blood platelets: a methodological report. Adv. Exp. Med. Biol. 34:235-243.

16. Timmons, S., and J. Hawiger. 1989. Isolation of human platelets by albumin gradient and gel filtration. Methods Enzymol. 169:11-21.

17. Tornai, I., P. J. Declerck, L. Smets, J. Arnout, H. Deckmyn, K. M. Caekebeke-Peerlinck, and J. Vermylen. 1991. Measurement of von Willebrand factor antigen in plasma and platelets with an enzyme-linked immunosorbent assay based on two murine monoclonal antibodies. Haemostasis. 21:125-134.

18. Fujimura, Y., K. Titani, L. Z. Holland, S. R. Russell, J. R. Roberts, J. H. Elder, Z. M. Ruggeri, and T. S. Zimmerman. 1986. von Willebrand factor. A reduced and alkylated $52 / 48-\mathrm{kDa}$ fragment beginning at amino acid residue 449 contains the domain interacting with platelet glycoprotein Ib. J. Biol. Chem. 261:381-385.

19. Laemmli, U. K. 1970. Cleavage of structural proteins during the assembly of the head of bacteriophage $T_{4}$. Nature (Lond.). 227:680-685.

20. Towbin, H., T. Staehelin, and J. Gordon. 1979. Electrophoretic transfer of proteins from polyacrylamide gels to nitrocellulose sheets: procedure and some applications. Proc. Natl. Acad. Sci. USA. 76:4350-4354.

21. Bradford, M. M. 1976. A rapid and sensitive method for the quantitation of microgram quantities of protein utilizing the principle of protein-dye binding. Anal. Biochem. 72:248-254.

22. Cattaneo, M., J. F. Mustard, M. T. Canciani, M. Richardson, A. B. Federici, and P. M. Mannucci. 1988. Conditions influencing the interaction of asialo von Willebrand factor with human platelets. The effects of external ionized calcium concentration and the role of arachidonate pathway. Thromb. Haemostasis. 60:280-288.

23. Warren, L. 1959. The thiobarbituric acid assay of sialic acids. J. Biol. Chem. 234:1971-1975.

24. Ey, P. L., S. J. Prowse, and C. R. Jenkin. 1978. Isolation of pure $\operatorname{IgG}_{1}$, $\mathrm{IgG}_{2 \mathrm{a}}$ and $\mathrm{IgG}_{2 \mathrm{~b}}$ immunoglobulins from mouse serum using protein A-sepharose. Immunochemistry. 15:429-436. 
25. Deckmyn, H., K. Nuyts, P. J. Declerck, B. Hoet, J. M. Stassen, I. Tornai, and J. Vermylen. 1991. A murine monoclonal antibody against platelet glycoprotein IIb/IIla potently inhibits platelet function in vitro and in vivo. Thromb. Haemostasis 65:843. (Abstr.)

26. Tijssen, P. 1985. Practice and theory of enzyme immunoassays. In Laboratory Techniques in Biochemistry and Molecular Biology. Vol. 15. R. H. Burdon, and P. H. Knippenberg, editors. Elsevier/North Holland, Amsterdam. 117-121.

27. MacFarlane, D. E., J. Stibbe, E. P. Kirby, M. B. Zucker, R. A. Grant, and J. McPherson. 1975. A method for assaying von Willebrand factor (Ristocetincofactor). Thromb. Diath. Haemorrh. 34:306-308.

28. Ruggeri, Z. M., L. De Marco, L. Gatti, R. Bader, and R. R. Montgomery. 1983. Platelets have more than one binding site for von Willebrand factor. $J$. Clin. Invest. 72:1-12.

29. Fraker, P. J., and J. C. Speck, Jr. 1978. Protein and cell membrane iodinations with a sparingly soluble chloroamide, 1,3,4,6-tetrachloro-3a,6a-diphenylglycoluril. Biochem. Biophys. Res. Commun. 80:849-857.

30. Montgomery, R. R., T. J. Kunicki, C. Taves, D. Pidard, and M. Corcoran. 1983. The diagnosis of Bernard-Soulier syndrome and Glanzmann's thrombasthenia with a monoclonal assay on whole blood. J. Clin. Invest. 71:385-389.

31. Berndt, M. C., X. P. Du, and W. J. Booth. 1988. Ristocetin-dependent reconstitution of binding of von Willebrand factor to purified human platelet membrane glycoprotein Ib-IX complex. Biochemistry. 27:633-640.

32. De Marco, L., A. Girolami, S. Russell, and Z. M. Ruggeri. 1985. Interaction of asialo von Willebrand factor with glycoprotein Ib induces fibrinogen binding to the glycoprotein IIb/IIIa complex and mediates platelet aggregation. $J$. Clin. Invest. 75:1198-1203.

33. Ruggeri, Z. M., and T. S. Zimmerman. 1981. The complex multimeric composition of factor VIII/von Willebrand factor. Blood. 57:1140-1143.

34. Fujimura, Y., K. Titani, L. Z. Holland, J. R. Roberts, P. Kostel, Z. M. Ruggeri, and T. S. Zimmerman. 1987. A heparin-binding domain of human von Willebrand factor. Characterization and localization to a tryptic fragment extending from amino acid residue Val-449 to Lys-728. J. Biol. Chem. 262:17341739.

35. Lawrie, A. S., P. Harrison, A. L. Armstrong, B. R. Wilbourn, R. G. Dalton, and G. F. Savidge. 1989. Comparison of the in vitro characteristics of von Willebrand factor in British and commercial factor VIII concentrates. Br. J. Haematol. 73:100-104.

36. Hamilton, K. K., L. J. Fretto, D. S. Grierson, and P. A. McKee. 1985. Effects of plasmin on von Willebrand factor multimers. Degradation in vitro and stimulation of release in vivo. J. Clin. Invest. 76:261-270.

37. Rink, T. J., and S. O. Sage. 1987. Stimulated calcium efflux from fura-2loaded human platelets. J. Physiol. (Lond.). 393:513-524.

38. Vermylen, J., M. B. Donati, G. de Gaetano, and M. Verstraete. 1973. Aggregation of human platelets by bovine or human factor VIII: role of carbohydrate side chains. Nature (Lond.). 244:167-168.

39. Federici, A. B., R. Bader, S. Pagani, M. L. Colibretti, L. De Marco, and P. M. Mannucci. 1989. Binding of von Willebrand factor to glycoproteins $\mathrm{Ib}$ and
IIb/IIla complex: affinity is related to multimeric size. Br. J. Haematol. 73:9399.

40. Stel, H. V., K. S. Sakariassen, B. J. Scholte, E. C. Veerman, T. H. van der Kwast, P. G. de Groot, J. J. Sixma, and J. A. van Mourik. 1984. Characterisation of 25 monoclonal antibodies to factor VIII-von Willebrand factor: relationship between ristocetin-induced platelet aggregation and platelet adherence to subendothelium. Blood. 63:1408-1415.

41. Sixma, J. J., K. S. Sakariassen, H. V. Stel, W. P. M. Houdijk, D. W. In der Maur, R. J. Hamer, P. G. de Groot, and J. A. van Mourik. 1984. Functional domains on von Willebrand factor. Recognition of discrete tryptic fragments by monoclonal antibodies that inhibit interaction of von Willebrand factor with platelets and with collagen. J. Clin. Invest. 74:736-744.

42. Hornsey, V., L. R. Micklem, M. C. McCann, K. James, J. Dawes, D. B. L. McClelland, and C. V. Prowse. 1985. Enhancement of factor VIII-von Willebrand factor ristocetin cofactor activity by monoclonal antibodies. Thromb. Haemostasis. 54:510-514.

43. Kao, K. J., S. V. Pizzo, and P. A. McKee. 1979. Demonstration and characterization of specific binding sites for factor VIII/von Willebrand factor on human platelets. J. Clin. Invest. 63:656-664.

44. Gralnick, H. R., S. B. Williams, and B. S. Coller. 1985. Asialo von Willebrand factor interactions with platelets. Interdependence of glycoproteins $\mathrm{Ib}$ and IIb/IIla for binding and aggregation. J. Clin. Invest. 75:19-25.

45. De Marco, L., M. Mazzuccato, M. Grazia-Del-Ben, U. Budde, A. B. Federici, A. Girolami, and Z. M. Ruggeri. 1987. Type IIB von Willebrand factor with normal sialic acid content induces platelet aggregation in the absence of ristocetin. J. Clin. Invest. 80:475-482.

46. Boeynaems, J. M., and J. E. Dumont. 1980. Outlines of receptor theory. Elsevier/North-Holland, Amsterdam.

47. Marti, T., S. J. Rosselet, K. Titani, and K. A. Walsh. 1987. Identification of disulfide-bridged substructures within human von Willebrand factor. Biochemistry. 26:8099-8109.

48. Titani, K., S. Kumar, K. Takio, L. H. Ericsson, R. D. Wade, K. Ashida, K. A. Walsh, M. W. Chopek, J. E. Sadler, and K. Fujikawa. 1986. Amino acid sequence of human von Willebrand factor. Biochemistry. 25:3171-3184.

49. Foster, P. A., C. A. Fulcher, T. Marti, K. Titani, and T. S. Zimmerman. 1987. A major factor VIII-binding domain resides within the amino-terminal 272 amino acid residues of von Willebrand factor. J. Biol. Chem. 262:8443-8446.

50. Azuma, H., J. A. Dent, M. Sugimoto, Z. M. Ruggeri, and J. Ware. 1991. Independent assembly and secretion of a dimeric adhesive domain of von Willebrand factor containing the glycoprotein Ib-binding site. J. Biol. Chem. 266:12342-12347.

51. Bockenstedt, P., P. K. Nguyen, T. Johnson, A. Yong, D. Foxand, and D. Ginsburg. 1988. Identification of a new functional von Willebrand factor domain facilitating binding to platelets. Blood. 72:1073. (Abstr.)

52. Kroll, M. H., T. S. Harris, J. L. Moake, R. I. Handin, and A. I. Schafer. 1991. von Willebrand factor binding to platelet GPIb initiates signals for platelet activation. J. Clin. Invest. 88:1568-1573. 